\title{
Gender, Age and Religion as Determinants of Voyeurism Among Undergraduates in Two Southwest Universities, Nigeria
}

\author{
Tosin .E. AKINDUYO (Ph.D) ${ }^{1} \quad$ Dr. TAYO-OLAJUBUTU, Olufunmilayo ${ }^{2}$ \\ Dr. Joseph Oluwatayo Osakuade ${ }^{3}$ \\ Department of Guidance and Counselling, Adekunle Ajasin University, Akungba-Akoko, P.M.B 001, Ondo \\ State, Nigeria
}

\begin{abstract}
In recent years, undergraduates' who are expected to engage in rigorous academic activities deviate to bizarre sexual behaviours(especially voyeurism) that are not culturally and religious acceptable across the world with enthusiasm. Hence, there is an urgent need to stop its prevalence among undergraduates. This study investigated the moderating roles of gender, age and religion on undergraduates' voyeuristic sexual behaviour in Southwest, Nigeria. A descriptive research design of the survey type was adopted for this study with 300 undergraduates selected from Adekunle-Ajasin University, Akungba-Akoko (AAUA) and Ekiti State University, Ado-Ekiti (EKSU) through multi-stage sampling procedure. The study was guided by one research question and three hypotheses. The formulated research hypotheses were all tested at 0.05 level of significance. Data collected were analysed using descriptive and inferential statistics. The study revealed that age, religion and gender of undergraduates have no influence on their voyeuristic sexual behaviour. Based on the findings, it was recommended that sex education should be revamped across tertiary institutions. University managements, parents and religious organizations should not only campaign against voyeurism but see to the non-involvement of undergraduates in voyeuristic sexual behaviour.
\end{abstract}

Keywords: Voyeurism, Undergraduates, Age, Gender, Religion.

DOI: $10.7176 / \mathrm{JEP} / 11-11-11$

Publication date: April $30^{\text {th }} 2020$

\section{Introduction}

Sexual health recently has unveiled series of behaviours which can be described as sources of concerns and paraphilic disorders. Behaviour such as voyeurism is generally and culturally described as deviations from acceptable sexual activity. Some cultures view voyeurism as a deviation from sexual behaviour and some societies view its engagement as aberration to human's sexual privacy. However, voyeurism tends to be a sexual behaviour that appears to be common among undergraduates across the world. This behaviour seems intruding into someone's privacy without the express permission of a victim.

Those who engage in voyeurism are called Voyeurs or Peeping Toms. Brown (2017) viewed voyeurism as fantasy or sexual arousal by secretly watching unsuspecting opposite sex who is naked, engaging in sexual activity or disrobing. Voyeurs intentionally watch the opposite sex who has not consented or expressly given permission to be watched. A particular population of vouyers are referred to as "upskirts" (that is, deriving sexual pleasure from looking at the underwear of clothing). Voyeurism could also be in the form of "down blouse," that is, looking at underwear or breast or other sensitive parts of the body when bending over (Berger, 2005).

Voyeurs tend not to be harmful when engaging the act and they do not necessarily have sexual contact with their victims. Majorly, voyeurs are sexually satisfied by watching victim's nakedness while in turn their testosterone increases their sexual drive which precedes normal ejaculation.

Brown (2017) posited that some undergraduates who are adolescents chiefly engage in voyeurism. According to Brown (2017) male adolescents have been reported to engage in voyeurism more than their female counterparts. Akinduyo (2019) argued that male adolescents' involvement in different sexual activities apart from hormonal secretions, could be caused by the outer location of the male genital organ (penis), which reduces male inhibitive strength to control their sexual drive most times.

Voyeurs tend to spend a lot of time in orchestrating their plans and properly act the sexual script. Voyeurism is an act that needs to be properly planned before engaging in it and go all out in looking for victims' nakedness to watch in order to satisfy their sexual urge. This might involve some undergraduates playing several pranks in order to carry out this act at the expense of their academic pursuit. Asides that, and because of the risk involved, any society a voyeur is caught, people may take laws into their hands before handing him/her to the law enforcement agents for proper prosecution. In an interaction with a voyeur, he revealed that his engagement in the act was an interesting and safest means of engaging in sexual activity. Some of the merits in voyeurism are that voyeurs cannot contract sexually transmitted infections, needs no financial commitment, no mutual emotional attachment, no in-law interference was not a factor and could be done as the voyeur pleases. He further stated that, the only requirement was to spy the nakedness of a non-consenting person.

Male undergraduates have a greater percentage of voyeurs across the world. They use different binoculars, 
mirrors and recording cameras to spy through holes and windows of the victims. Records have shown that, male undergraduates record sexual acts, which they later view to get sexual gratification, masturbate or have sexual fantasies (Psychology Today, 2019). Voyeurism have been reported to be more prevalent among males at $12 \%$ and 4\% among females, to this end, males are 3 times into voyeurism more than the females (Patricelli, 2019). Males were reported to chiefly engage in voyeurism more than their female counterparts. Overwhelming population of male adolescents are addicted to this paraphilic behaviour in order to get sexual pleasure (Beech and Harkins, 2012).

Both male and female undergraduates were argued to be engaged in voyeurism and were revealed to fantasize and engage in voyeurism to satisfy their sexual urges (Langervin, Lang and Curnoe, 1998; O'Donohlie, Letourneau and Dowling, 1997; Sierra, Ortega and Zubedidat, 2006; Smith and Over, 1991; Zurbriggen and Yost, 2004).These researchers did not observe any difference in the behaviour of both male and female towards voyeurism.

Voyeurism could also be referred to as Scopophilia. The term scopophilia was derived from Greek words Skopeo which means "to see" and philia "to love". It is the innate desire to look erotic content to achieve sexual gratification (Kieran, 2016). Males have been found to spend more time and engage in voyeurism than females. Females who do not use contraceptives were chief voyeurs who derive pleasure in watching male genitals (Rupp and Wallen, 2007).

Adolescents were reported to have their first voyeurism engagement between 13-15 years of age. At about age 16, undergraduates developed intense voyeuristic desire, that they could not resist by spying on the opposite sex (Yalcin, Guney and Saripinar, 2014). Age tends not to greatly influence voyeuristic sexual behaviour, because the chief aim of engaging in it is for sexual pleasure. Encyclopaedia of mental disorders (2019) reported that the onset of voyeurism is usually before the age of 15 years. After the first sexual debut, it increases with time, therefore causing chronic attitude which makes sexual gratification focussing on peeping alone. Brown (2017) found that voyeurism begins during adolescent period without any age limit or barrier to voyeur's constant engagement in the sexual act. Voyeurs' persistent viewing of non-consenting victim which is the hallmark of voyeurism depends on so many other factors, which make the behaviour not to be influenced by age.

Religion appears to frown against voyeurism in any form it may appear. Christianity, Islam and African Traditional religions tag voyeurism as ungodly act and sin against the almighty God. Duff (2018) cited Mathew 5:28 where the bible revealed that Jesus Christ referred to voyeurism as adultery which is a sin before God. Raven (1999) posited that religion helps to instil discipline in individuals which in turn exert an element of social control against voyeurism.

Voyeurism maybe treated as a crafty sexual deviant behaviour. Mckeon (2019) reported that men that spy the breasts or bodies of women violate their rights and should be made to face the wrath of the law. Some men were reported using pen camera to record female sexual activities or nudity. Even if men are found guilty of voyeurism in the court of law, punishment are not meted out to voyeurs on time, which does not serve as deterrent to others. However, female gender is the major victim of voyeurism. No matter the form voyeurism takes, it is simply a crime against girls and women. According to Mckeon (2019) out of 59 voyeurism cases, only three cases were male victims. The Canadian women's foundation reported that $70 \%$ of Canadian women were sexually harassed before attaining the age of 15years.

Voyeurism appears to be a hidden and well-orchestrated offence among undergraduates across the world. Pauldriks (2017) reported that most males are voyeurs and may be virtually impossible to stop it in the society. It was described as a hidden monster in all cultures, being promoted by daily technological advancement. Many victims (mostly women) reported that, the consequences of voyeurism on them includes post traumatic disorder, weird dreams about being watched, sleep-deprivation and fear for safety. Dawson, Bannerman and Lalumiere (2016) found out that men were chiefly less repulsive to voyeurism and were more aroused by several sexual paraphilia. According to them men invest more time trying varieties of paraphilic acts, without exemption to voyeurism to satisfy their sexual gratification.

Sadly, voyeurism may pose serious danger to the development of any nation and academic pursuit of undergraduates. A nation's development maybe retarded when undergraduates who are to develop through scholarly activities devote more time to spying the nudes of non-consenting persons. It tends to be dangerous to undergraduates, because when caught, their reputations and academic attainments are compromised. Strgar (2011) reported voyeurism as a mixture of pain and pleasure. The same body chemicals and hormones secreted during pain, love, sex and violence are constantly secreted during undergraduates' engagement in voyeurism. Human bodies release epinephrine and norepinephrine when experiencing pain, but later transform the circumstance into pleasurable rush. A typical example could be seen during orgasmic release. This pleasure and pain scenario being experienced during sexual activities seems signals "wear and tear syndrome" among undergraduates. Unfortunately, this syndrome could be linked to displacements of time, energy, excellent academic attainment and concentration. Constant engagement in voyeurism may quickly sap energy required by undergraduates to properly engage in profitable tasks. The researcher therefore intend to investigate the moderating roles of age, religion and gender on undergraduates engagement in voyeurism in Southwest, Nigeria. 


\section{Research Question}

Only one research question was raised to guide the study:

1.What are the demographic data of undergraduates engaging in voyeurism?

\section{Research Hypotheses}

1. Age has no significant influence on undergraduates' voyeuristic behaviour.

2. Religion has no significant influence on undergraduates' voyeuristic sexual behaviour.

3. There is no significant difference between male and female undergraduate' voyeuristic sexual behaviour.

\section{Methodology}

Descriptive research design of the survey type was used for the study, because the study investigated age, gender and religion as determinants of undergraduate's engagement in voyeurism in Southwest Nigeria. The population of the study was all undergraduates in Southwest, Nigeria. Multi-stage sampling procedure was employed for this study. At stage one, convenience sampling technique was used to select two public universities from Southwest Nigeria, while stage two involved the use of simple random sampling technique to select 150 undergraduates from each of the two universities. A self-developed questionnaire entitled "voyeurism among undergraduate questionnaire (VAUQ)" was used for data collection. The instrument's face and content validity were ensured by giving to two psychologists who screened and modified some of the items. The reliability of the instrument was carried out through test-retest method and Pearson Product Moment Correlation was applied and a reliability coefficient of 0.74 was obtained which showed that the instrument was reliable enough for the study. The researcher personally administered the instrument and collection was done on the spot. The data collected were analysed using simple percentage, mean, t-test and ANOVA statistics.

\section{Results}

Research Question: What are the demographic variables of undergraduates engaging in voyeurism? Distribution of participants by Age, Gender and Religion

\begin{tabular}{|c|c|c|c|}
\hline $\mathbf{S} / \mathbf{N}$ & Variables & Frequency & Percentage (\%) \\
\hline \multirow[t]{2}{*}{1.} & $\begin{array}{l}\text { Age } \\
16-20 \text { Years } \\
21-25 \text { Years } \\
26 \text { Years and above }\end{array}$ & $\begin{array}{c}144 \\
102 \\
54 \\
\end{array}$ & $\begin{array}{l}48.0 \\
34.0 \\
18.0\end{array}$ \\
\hline & Total & 300 & 100.0 \\
\hline \multirow[t]{2}{*}{2.} & $\begin{array}{l}\text { Gender } \\
\text { Male } \\
\text { Female }\end{array}$ & $\begin{array}{l}176 \\
174 \\
\end{array}$ & $\begin{array}{l}42.0 \\
58.0 \\
\end{array}$ \\
\hline & Total & 300 & 100.0 \\
\hline \multirow[t]{2}{*}{3.} & $\begin{array}{l}\text { Religion } \\
\text { African Traditional Religion } \\
\text { Christianity } \\
\text { Islam }\end{array}$ & $\begin{array}{c}23 \\
132 \\
145 \\
\end{array}$ & $\begin{array}{r}7.7 \\
44.0 \\
48.3 \\
\end{array}$ \\
\hline & Total & 300 & 100.0 \\
\hline
\end{tabular}

Table 1 presents demographic information about the respondents that participated in the study. The table shows that out of 300 respondents selected from the study, 144(48\%) were between 16 - 20 years old, 102 (34\%) were within the age range of 21-25years old and 54 (18\%) were between 26years and above. The table further shows that $126(42 \%)$ males and $174(58 \%)$ females participated in the study. Furthermore, $23(7.7 \%)$ respondents practiced African traditional religion, 132 (44\%) were Christians, while 145 (48.3\%) respondents practiced Islam.

\section{Hypotheses Testing}

Hypothesis One: Age has no significant influence on undergraduates' voyeuristic behaviour.

Table 2: Analysis of Variance (ANOVA) showing influence of Age on undergraduates' voyeuristic sexual behaviour

\begin{tabular}{lcclcl}
\hline Sources & SS & df & MS & F & P-value \\
\hline Between groups & 3.174 & 3 & 3308.942 & & \\
Within groups & 167.013 & 296 & 0.52 & 2.822 & 0.61 \\
Total & 170.187 & 299 & & & \\
\hline
\end{tabular}

Table 2 shows that the exact probability value of 0.61 is greater than 0.05 significant level. This null 
hypothesis was not rejected. This implies that there was no significant influence of age on undergraduates' voyeuristic sexual behaviour. By implication, age is not a barrier undergraduates' involvement in voyeurism.

Hypothesis Two: Religion has no significant influence on undergraduates'voyeuristic sexual behaviour. Table 3: ANOVA Summary of the influence of religion on undergraduates' voyeuristic sexual behaviour.

\begin{tabular}{lccccc}
\hline Sources & SS & df & MS & F & P-value \\
\hline Between groups & 1.775 & 2 & 0.88 & & \\
Within groups & 168.411 & 297 & 0.569 & 1.56 & 0.211 \\
Total & 170.187 & 299 & & & \\
\hline
\end{tabular}

Table 3 shows that a calculated F-value of 1.56 with a calculated significant value of 0.211 at 0.05 alpha level. Since the exact probability value of 0.211 is greater than 0.05 significant level, the null hypothesis is, therefore not rejected. Hence, religion has no significant influence on undergraduates' voyeuristic sexual behaviour.

Hypothesis Three: There is no significant difference between male and female undergraduate' voyeuristic sexual behaviour.

Table 4: t-test analysis showing the influence of gender on undergraduates' voyeuristic sexual behaviour

\begin{tabular}{lcccccc}
\hline Gender & N & Mean & SD & df & T & Sig. value \\
\hline Male & 126 & 3.380 & 0.88 & & & \\
Female & 174 & 3.367 & 0.813 & 298 & 0.149 & 0.882
\end{tabular}

Table 4 shows a calculated t-value of 0.149 with calculated significant value of 0.882 at 0.05 alpha level. Hypothesis three is not rejected since the exact calculated significance of 0.882 is greater than 0.05 alpha level. By implication, there was no significant difference between male and female undergraduates' voyeuristic sexual behaviour.

\section{Discussion}

This study revealed that age has no significant influence on undergraduates' voyeuristic behaviour. This finding is in agreement with that of Encyclopaedia of mental disorder (2019) that reported age of voyeurs after the first debut does not determine how often they engage in voyeuristic sexual behaviour. Brown (2017) also found that voyeurism starts during early adulthood or adolescence, after which the engagement in the sexual act increases till death except being treated through psychotherapy support groups, certain antidepressants (called selective serotonin re-uptake inhibitors) and other drugs. This might also be as a result of peer influence and unlimited access to pornography. There is no doubt that, these factors initiate them to so many sexually deviant behaviours which against the norms of the society.

Another finding revealed that religion has no significant influence on undergraduates' voyeuristic sexual behaviour. This is in disagreement with that of Raven(1999) who found that commitment to a particular religion prevents undergraduates' engagement in voyeurism. The plausible reason for this finding might be that, many undergraduates are adolescents. The period of adolescence is full of physic energy and libido reactivation which makes an individual that belongs to the age-group to consciously and unconsciously seek for fulfilment of their sexual pleasure. Many adolescents without religion as a determinant factor, engage in voyeurism chiefly to get the much desired sexual pleasure.

The finding in hypothesis three showed that there was no significant difference between male and female undergraduates voyeuristic sexual behaviour. This contradicts the finding of Brown(2017) which revealed that male undergraduates engage more in voyeurism than their female counterparts. The plausible reason why both gender engage in voyeurism might be as a result of factors such as peer influence, school type and family upbringing among other factors. These factors do not really consider gender as a factor to consider in the undergraduates engagement in voyeurism.

\section{Counselling Implications}

Professional counsellors should help undergraduates build positive attitude towards sexual behaviour especially during adolescence.

Professional counsellors can be employed into various department in the universities to help reduce the scourge of voyeurism.

Professional counsellors as a matter of duty, should enlighten undergraduates about the demerits of engaging 
in voyeurism because they might not be aware of the disadvantages.

Professional counsellors should involve various students' association on campuses to create awareness against voyeurism.

\section{Conclusion}

Based on the findings of the study. It was concluded that age, religion and gender have no influence on undergraduates' voyeuristic sexual behaviour. On the strength of the findings from this study, undergraduates at all age groups engage in voyeuristic sexual behaviour. Each undergraduate practice a particular religion out of the three major religions in Nigeria, but religious affiliation does not prevent undergraduates from engaging in voyeurism. Finally, gender does not in any way affect undergraduates' involvement in voyeuristic sexual behaviour.

\section{Recommendations}

Based on the findings of this study, it was recommended that:

(i) there is need to revamp sex education among all age groups of undergraduates in all tertiary institutions.

(ii) religious association should not only campaign against undergraduates' engagement in voyeurism but effect actions that will prevent involvement in voyeuristic sexual behaviour.

(iii) professional counsellors in collaborations with university management should constantly organise seminars and public enlightenment for both male and female undergraduates on the issue of their reproductive health.

\section{REFERENCES}

Akinduyo, T.E. (2019). Sexual behaviour and contraceptive usage among undergraduates in Southwest, Nigeria(Ph.D thesis). Faculty of Education, Ekiti State University, Ado- Ekiti, Nigeria.

Beech, A. R \& Harkins, L. (2012). DSM-IV Paraphilic Description, demographics and treatment interventions. Aggressive Violent Behaviour, 7, 527-393.

Brown, R. G (2017). Voyeurism. MSD Manual Consumer Version. Retrieved from http://www.msdmanuals.come/home/mental-health-disorders/sexuality/voyeurism.

Dawson, S.J., Bannerman, A. B. \& Lalumiere, M. (2016). Paraphilic Interests. An examination of sex differences in a non-clinical sample: Sexual Abuse: A Journal of Research and Treatment, 28(1), 20-45.

Duff, S. (2018). Voyeurism: A case study. Retrieved from http://doi.org/10/107/978-3-319- 971605.

Encyclopedia of Mental Disorders (2019). Voyeurism. Minddisorders.com/py-z/ voyeurism.html.

Kieran, P (2016). A study of neurosis through the lens of scopophilia (Master's thesis).Dublin Business School, School of Arts.

Langevin, R., Lang, R., \& Curnoe, S. (1998). The Prevalence of Sex Offenders with deviant fantasies. Journal of Interpersonal Violence, 13,315-317.

Mckeon, L. (2019). Why voyeurism should be treated as gender-based violence.Retrieved from https://www.tvo.org/article/why-voyeurism-should-be-treated-as-gender-based- violence.

O’Donohue, W., Letourneau, E. J., \& Dowling, H. (1997), Development and preliminary validating of a paraphilic sexual fantasy questionnaire. Sexual Abuse: A Journal of Research and Treatment; 9,167-178.

Patrielli, K. (2019). Voyeuristic-Disorder: Southwest Alabama Behavioural Health Care Systems. Retrieved from http://www.swamh.com/poc/view-doc.php?type=doc \& id = 602 30/3/2019

Pauldrik (2017). Voyeurism Epidemic. Retrieved from http://womanmeanssomething.com /the-voyeurismepidemic.

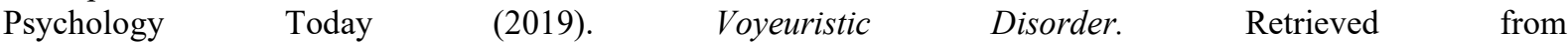
https://www.psychologytoday.com/ca/conditions/voyeuristic-disorder.

Raven, B. H. (1999). Kurt Lewin address: Influence, power, religion and the mechanisms of social control. Journal of social issues, 55(1), 161-186.

Rupp, H. \& Wallen, K. (2007). Sex differences in viewing sexual stimuli: An eye-tracking study in men and women. Hormones and Behaviour 51(4), 524- 533.

Seto, M.C. (2008). Pedophilia and Sexual Offending against children. Washington, DC: American Psychological Association.

Sierra, J.C., Ortega, V., \& Zubeidat, T. (2006), Confirmatory factor analysis of a Spanish version of the sex fantasy questionnaire: Assessing gender differences. Journal of Sex and Marital Therapy, 32, 137-159.

Smith, D., \& Over, R. (1991). Male Sexual Fantasy: Multidimensionality in content. Behaviour Research and Therapy, 29, 267-275.

Strgar, W. (2011). The connection between sexual pain and pleasure. Retrieved from huffpost.com/entry/theconnection-between-se-b-913420. 
Yalcin, O., Guney, E. \& Saripinar (2014). Dramatic Improvement with Sertraline in a male adolescent with voyeurism. Bulletin of Clinical Psychopharmacology, 24(3), 292-294.

Zurbriggen, E. L, \& Yost, M.R. (2004). Power, desire and pleasure in sexual fantasies. The Journal of Sex Research, $41,288-300$.

\section{Acknowledgements}

The researchers thank all respondents for their participation and authors cited in this study. Dr L.O Gbore's scholarly comments are acknowledged. 